\title{
Correction to: Fighting capital flight in Nigeria: have we considered global uncertainties and exchange rate volatilities? Fresh insights via quantile ARDL model
}

\section{Emmanuel Uche ${ }^{1}\left[\right.$ ] $\cdot$ Lionel Efom ${ }^{2}$}

Published online: 7 July 2021

๑) Springer Nature Switzerland AG 2021

\section{Correction to: SN Bus Econ (2021) 1:73 https://doi.org/10.1007/s43546-021-00082-5}

The article was published with an error in the first sentence of the abstract. The sentence was corrected as follows:

This study aims to fill the observed gap in the literature related to capital fight and its determinants.

No other changes to the article have been made. We apologise for any inconvenience caused to our readers.

Publisher's Note Springer Nature remains neutral with regard to jurisdictional claims in published maps and institutional affiliations.

The original article can be found online at https://doi.org/10.1007/s43546-021-00082-5.

Emmanuel Uche

uche.emmanuel@abiastateuniversity.edu.ng

Lionel Efom

leoef2002@yahoo.com

1 Department of Economics, Abia State University, Uturu, Abia, Nigeria

2 Department of Economics, University of Calabar, Calabar, Cross River, Nigeria 